\title{
Zagadnienia prawne systemu dochodów samorządu powiatowego i propozycje jego reformy
}

\section{The revenues system of the counties in Poland and proposals for its reform}

Streszczenie. Obecny system dochodów samorządu powiatowego budzi zastrzeżenia i powinien być zmieniony. Powiat ma dwie formy: powiatu ziemskiego (złożonego z wielu samodzielnych gmin) i miasta na prawach powiatu (dużego miasta mającego z reguły powyżej 100 tys. mieszkańców). W opracowaniu wskazuje się, że trzeba stworzyć odrębny system dochodów powiatów ziemskich i odrębny, właściwy dla miast na prawach powiatu, system dochodów tych miast. Źródła podatkowe, udziały, subwencje, dotacje należy zbudować oddzielnie dla tych dwóch różnych typów samorządów. Posiadają one swą specyfikę ustrojową, organizacyjną, społeczną, gospodarczą, demograficzną.

Słowa kluczowe: powiaty w Polsce; system dochodów powiatów ziemskich i miast na prawach powiatu; propozycje reform.

Abstract. There are two types of the counties in Poland: land county (encompassing a number of small towns and communes) and urban county (a large town 
above 100000 inhabitants). The current system of budget revenues of the counties is doubtful and should be changed. This article presents proposals for creating of land county revenues system and a separate system for revenues of large towns. Local taxes, subventions, grants must be built separately for these two different types of local governments.

Keywords: counties in Poland; system of budget revenues of land and urban counties; new proposals for revenues of counties.

\section{Uwagi wstępne}

Występują dwa typy powiatowych samorządów terytorialnych. Są to odrębne miasta wyłączone z powiatu (powiaty miejskie) oraz powiaty ziemskie, obejmujące swym zasięgiem terytorialnym kilka (lub kilkanaście) mniejszych miast oraz gmin wiejskich. Miasta będące powiatami miejskimi (miasta na prawach powiatu) są to duże gminy miejskie.

Dla pozycji społecznej i gospodarczej powiatów kluczową sprawą jest system dochodów samorządu powiatowego. Od struktury i znaczenia tego systemu zależy, czy powiaty będą odgrywać istotną rolę. Obecny system dochodów samorządu powiatowego, w tym system subwencji oraz wpłat do budżetu państwa, budzi różne zastrzeżenia. Szczególne problemy związane są z tym, że powiat ma dwie formy: powiatu ziemskiego (złożonego z wielu samodzielnych gmin) i miasta na prawach powiatu. Zbudowanie dobrego systemu dochodów tych dwóch typów samorządu jest trudne.

Niniejsze opracowanie służy przedstawieniu i ocenie dochodów powiatów i dochodów miast na prawach powiatu. W szczególności badane będą niektóre aspekty dochodów własnych samorządu powiatowego, powiatowych subwencji wyrównawczych, wpłat do budżetu państwa, a także dochodów związanych z działalnością gospodarczą powiatów.

W opracowaniu zarysowana jest także propozycja reformy systemu dochodów powiatowych, zwłaszcza w zakresie dochodów powiatów ziemskich.

Znaczenie miast na prawach powiatów jest bardzo istotne. Jednostek tych jest 66. Są to duże miasta, mające z reguły powyżej 100 tys. miesz- 
kańców. Obejmują one większość ludności kraju. Budżety tych jednostek stanowią zasadniczą część dochodów i wydatków ogółu samorządów terytorialnych w Polsce. W podziale na: gminy, miasta na prawach powiatu, powiaty (ziemskie) i województwa samorządowe miasta na prawach powiatu stanowią najsilniejszą grupę samorządów. Natomiast powiaty ziemskie (których jest 314), są to stosunkowo słabe finansowo jednostki.

\section{Stan obecny w zakresie dochodów samorządu powiatowego}

Budżety miast na prawach powiatu ujmowane są obecnie w dwóch płaszczyznach - gospodarki budżetowej gminy (miejskiej) oraz gospodarki budżetowej powiatu ziemskiego.

Dochodami własnymi miast na prawach powiatu o charakterze publicznoprawnym są podatki lokalne, opłaty samorządowe oraz udziały w podatkach dochodowych. Są to: podatek od nieruchomości, podatek rolny, podatek leśny, podatek od środków transportowych, podatek od spadków i darowizn, karta podatkowa, podatek od czynności cywilnoprawnych, opłata skarbowa i inne daniny lokalne, a także udział w podatku dochodowym od osób fizycznych (ok. 38\% kwoty podatku) i udział w podatku dochodowym od osób prawnych (6,71\% podatku).

Natomiast dochodami podatkowymi powiatów ziemskich są jedynie dwa udziały podatkowe: udział w podatku dochodowym od osób fizycznych (10,25\% wpływów z tego podatku) i udział w podatku dochodowym od osób prawnych (1,40\% kwoty podatku). Powiaty ziemskie nie mają żadnego własnego „pełnego” źródła podatkowego (mają tylko udziały), miasta na prawach powiatu mają zaś cztery udziały (dwa gminne i dwa powiatowe) i kilkanaście własnych podatków.

Na podstawie tak ukształtowanych dochodów podatkowych tych dwóch wspólnot samorządowych budowane są następnie subwencje wyrównawcze i wpłaty do budżetu państwa. W przypadku subwencji i wpłat miast na prawach powiatu powstają odrębnie następujące płatności: subwencja wyrównawcza dla miasta działającego jako gmina i subwencja wyrównawcza dla miasta działającego jako powiat, wpłata do budżetu 
państwa dokonywana przez miasta (jako gminy miejskiej) i wpłata do budżetu państwa tego miasta, działającego jako powiat. Dla miasta na prawach powiatu obliczany jest wskaźnik $\mathrm{G}$ (dochody podatkowe gminy na jednego mieszkańca) i - niezależnie od tego - wskaźnik P (dochody podatkowe powiatu na jednego mieszkańca). Miasto może więc uzyskać gminną subwencję wyrównawczą i jednocześnie może odprowadzić powiatową wpłatę wyrównawczą (ze względu na wysoki wskaźnik P). Obliczenie powiatowej subwencji wyrównawczej przeprowadzane jest jednocześnie, według tych samych zasad, dla dwóch typów samorządów powiatowych: powiatu ziemskiego i miasta na prawach powiatu, przy zastosowania wskaźników P i Pp.

System dochodów miasta na prawach powiatu jest zagmatwany i nadmiernie rozbudowany. Utrudnia zarówno ocenę, jak i funkcjonowanie finansów miast na prawach powiatów, albowiem są one ujmowane oddzielnie, w części gminnej i w części powiatowej, tak jakby to były dwa samorządy.

Sądzę, że należy stworzyć odrębny, samodzielny system dochodów powiatów ziemskich i odrębny, właściwy dla miast na prawach powiatu system dochodów tych miast. Źródła podatkowe, udziały, subwencje, dotacje należy zbudować oddzielnie dla tych dwóch różnych typów samorządów, posiadających swą specyfikę ustrojową, organizacyjną, społeczną, gospodarczą, demograficzną. Potrzebne jest odmienne prawne ukształtowanie dochodów dla powiatów ziemskich i dla miast na prawach powiatu.

Obecny system dochodów powiatowych zakłada, że powiaty i miasta na prawach powiatu są jednostkami porównywalnymi. Sprawia to, że część powiatowa dochodów miast na prawach powiatu i dochody powiatów ziemskich są zbudowane analogicznie (dwa udziały o takiej samej wysokości w zakresie dwóch podatków dochodowych - 10,25\% i 1,40\%). Założenie to jest jednak bardzo wątpliwe, mechanicznie łączy finansowanie zadań przez dwie różne wspólnoty. Są to wspólnoty nieporównywalne: duże, z reguły silne finansowo, miasto i stosunkowo słaba jednostka o cechach struktury rozproszonej, wiejskiej, o słabych źródłach podatkowych. Uważam, że należy niezależnie budować systemy dochodowe tych 
wspólnot. Zakładając, że wspólnota miasta na prawach powiatu ma już w dużym stopniu ukształtowany system dochodów własnych, należy się skupić na budowie systemu dochodów powiatów ziemskich.

\section{Propozycje zmian w systemie źródeł dochodów powiatu}

Biorąc pod uwagę aktualne uwarunkowania prawne i faktyczne, trzeba ukształtować taki system dochodów powiatów ziemskich, aby nie naruszyć zbyt mocno stosowanego obecnie systemu dochodów gmin i - tym samym - miast na prawach powiatu (tj. dużych, silnych finansowo gmin). Z prawnego, formalnego punktu widzenia dochody podatkowe małej gminy i dużego miasta (na prawach powiatu) są takie same. Określa je art. 4 ustawy z 13 listopada 2003 r. o dochodach jednostek samorządu terytorialnego ${ }^{1}$. Z uwagi na potrzebę zachowania realizmu w zakresie nowych propozycji należy te dochody - przynajmniej dla potrzeb niniejszego opracowania - pozostawić bez zmian.

Natomiast dochody powiatów ziemskich, i tylko tych samorządów, należy rozbudować, przez powiększenie poziomu udziałów podatkowych z obecnych 10,25\% do co najmniej 15\% (gdy chodzi o podatek dochodowy od osób fizycznych) i z obecnych $1,4 \%$ do co najmniej 5\% (gdy chodzi o podatek dochodowy od osób prawnych). Powiększenie to nie dotyczyłoby dochodów miast na prawach powiatu, mających nieporównywalnie większe możliwości finansowe w stosunku do możliwości powiatów ziemskich.

Przykładem odnoszącym się do dochodów powiatów jako jednostek samorządu terytorialnego są regulacje dotyczące dochodów powiatowych związków samorządowych z okresu II Rzeczypospolitej. Przepisy ustawy z dnia 11 sierpnia 1923 r. o tymczasowym uregulowaniu finansów komunalnych ${ }^{2}$ określają źródła dochodów poszczególnych związków samorządu terytorialnego II Rzeczypospolitej. Dochodami powiatowych związków samorządu terytorialnego były odpowiednie źródła podatkowe, z któ-

\footnotetext{
Tekst jedn. Dz.U. z 2015 r., poz. 513.

Tekst jedn. Dz.U. z 1936 r. Nr 62, poz. 454.
} 
rymi związek powiatowy musiał się dzielić z gminą wiejską lub też z miastem niewydzielonym z powiatowego związku.

Zgodnie $\mathrm{z}$ art. 3 ustawy o tymczasowym uregulowaniu finansów komunalnych z łącznego obciążenia gruntów i budynków położonych na obszarze gmin wiejskich podatkami komunalnymi korzystać mogą gminy wiejskie do wysokości 40\%, a powiatowe związki samorządowe do wysokości 50\%. Według art. 4 ust. 7 omawianej ustawy z łącznego obciążenia gruntów na obszarze miast podatkami komunalnymi miasta niewydzielone mogą korzystać do wysokości 70\%, a powiatowe związki samorządowe do wysokości 20\%, zaś miasta wydzielone do wysokości 90\%.

Według art. 8 ustawy wpływy z podatku komunalnego od przemysłu i handlu przypadają: a) miastom - co do podatku od przedsiębiorstw i zajęć wykonywanych na obszarze miast, b) powiatowym związkom samorządowym - co do podatku od przedsiębiorstw i zajęć wykonywanych na obszarze gmin wiejskich. Powiatowe związki samorządowe obowiązane są jednak tym gminom wiejskim, na których obszarze wymienione wyżej przedsiębiorstwa i zajęcia są wykonywane wypłacić połowę uzyskanej sumy.

Przepisy art. 9 ustawy stanowią, że miasta otrzymują udział 15\% (a m.st. Warszawa 20\%) we wpływach z państwowego podatku dochodowego, przypisanego w tychże miastach, powiatowe zaś związki samorządowe udział $15 \%$ we wpływach $\mathrm{z}$ państwowego podatku dochodowego, przypisanego w gminach wiejskich. Powiatowe związki samorządowe mogły pobierać (art. 11) na obszarze gmin wiejskich komunalne dodatki do państwowych opłat od wyrobu, przerobu i sprzedaży napojów alkoholowych, jednak połowę pobranej sumy przekazują przy tym gminom wiejskim, na których obszarze wykonywane są wspomniane przedsiębiorstwa i zajęcia.

Dochody powiatowych związków samorządowych opierały się więc na podatkach i udziałach w określonych podatkach. Subwencje, dotacje i inne transfery z budżetu Państwa były zaś źródłami o drugoplanowym znaczeniu.

Przykład II RP wskazuje, że powiat ziemski może być więc podatkowo powiązany ze „swoimi” gminami. Powiat i należące do niego gminy 
mogą i powinny tworzyć związek, także w płaszczyźnie podatkowej. Obecnie jednak inny podział podatków samorządowych pomiędzy powiaty i należące do nich gminy jest mało realny. Zakłóciłby utrwalone poziomy finansowania zadań gminnych. Nowy podział podatków zburzyłby także system wyrównań finansowych stosowanych w układzie gmin (których jest, łącznie z miastami na prawach powiatu - 2479), dotyczących sposobu obliczania subwencji wyrównawczych i wpłat gmin do budżetu państwa. Realnym rozwiązaniem jest więc powiększenie (wspomniane wyżej) udziałów podatkowych dla powiatów ziemskich.

Postulowane odseparowanie systemu dochodów miast na prawach powiatu od systemu dochodów powiatów ziemskich sprawi, że nie byłoby potrzeby stosowania w systemie miast na prawach powiatu dwóch subwencji wyrównawczych (gminnej i powiatowej) i dwóch wpłat do budżetu państwa (gminnej i powiatowej). Zniknie system podwójnego (i merytorycznie trudnego do zaakceptowania) liczenia - w miastach na prawach powiatu - dwóch subwencji wyrównawczych i dwóch wpłat. W miastach tych pozostaną tylko subwencje i wpłaty gminne.

Ukształtowany przez regulacje prawne z 2003 r. system dochodów powiatowych bardzo utrudnia jakikolwiek ruch (zmianę) w systemie dochodów gmin, miast na prawach powiatów i powiatów. Poruszenie jednego elementu dochodów tych wspólnot sprawia, że całość (w związku z podstawami liczenia subwencji wyrównawczych i wpłat) ulega załamaniu. Tymczasem systemy dochodów samorządów nie powinny być podporządkowane sztywnej konstrukcji, opartej o wątpliwe racje co do zrównania dochodów o charakterze powiatowym (takie same udziały) powiatów ziemskich i silnych finansowo miast na prawach powiatów. Należy dostosować dochody różnych typów samorządu do ich charakteru i natury, trzeba zwiększyć dochody podatkowe powiatów ziemskich.

W następstwie proponowanych zmian system finansowy gmin nie ulegnie istotnej zmianie. W systemie tym będą te same dochody podatkowe, stosowana będzie, tak jak do tej pory, gminna subwencja i wpłata wyrównawcza (obliczana w oparciu o wskaźnik G i Gg). W miastach na prawach powiatu obliczanie subwencji wyrównawczych i wpłat będzie odbywało się według tych samych danych, co w pozostałych gminach 
(m.in. w oparciu o gminne udziały: 37,67\% i 6,71\%). Jednak „powiatowy” udział miast na prawach powiatu w podatkach dochodowych (10,25\% i 1,40\%) miałby charakter „dodatku powiatowego” dla tych miast, który zresztą mógłby zostać zredukowany. Zlikwidowane zaś będą dotyczące tych miast „powiatowe” subwencje o charakterze wyrównawczym (które w istocie występują w niewielkiej skali) i „powiatowe” wpłaty tychże miast do budżetu państwa.

Natomiast system dochodów powiatów ziemskich - w razie wprowadzenia wskazanych propozycji - zmieni się istotnie. Oparty będzie głównie o dwa nowe, powiększone udziały podatkowe (wspomniane co najmniej 15\% i 5\%). Wyrównania poziome (mające formę wpłat do budżetu państwa) zachodzące pomiędzy powiatami ziemskimi i miastami na prawach powiatu ulegną zniesieniu. Liczenie wskaźnika P i Pp będzie potrzebne tylko dla celów subwencji wyrównawczej stosowanej dla finansowania powiatów ziemskich i dla ustalania wpłaty do budżetu państwa dokonywanej przez powiaty ziemskie. Subwencja wyrównawcza i wpłata do budżetu państwa stosowane byłyby - w systemie powiatowym - jedynie na poziomie powiatów ziemskich.

Miasta na prawach powiatu objęte byłyby natomiast systemem subwencji wyrównawczej i wpłat do budżetu państwa tylko jako jednostki należące do systemu gmin. Stosowanie dla tych miast jednego (tylko gminnego) mechanizmu wyrównań finansowych wydaje się wystarczające. Dla danego typu samorządu (w tym przypadku miasta na prawach powiatu) należy zastosować tylko jeden rodzaj subwencji wyrównawczej i wpłaty do budżetu państwa.

Z punktu widzenia polityki rozwoju regionalnego dużo większe środki finansowe (podatkowe) powinny być lokalizowane w słabych finansowo powiatach ziemskich, które muszą zyskać istotne źródła finansowania. W przeciwnym razie nie będą się rozwijać. Obecny system dochodów powiatowych i mechaniczne powiązanie dochodów powiatów ziemskich i powiatowej części dochodów miast na prawach powiatów uniemożliwia dokonanie poważniejszych zmian. Sprawia, że powiaty ziemskie stały się strukturą słabą, o niewielkich możliwościach finansowych, niezdolną do prowadzenia działalności na większą skalę, strukturą 
tylko usługowo-administracyjną. Nie mają one istotnych cech samorządu terytorialnego, opartego o istotne dochody własne.

Idea wyrównań poziomych (tj. stosowanie wpłat do budżetu państwa na rzecz finansowania innych samorządów) jest ważna i powinna być stosowana, jednak nie w sposób totalny, wszechogarniający. Na obecnym etapie rozwoju polskich samorządów i ich finansów praktyka jej stosowania musi być ograniczona do poziomu gmin (w tym miast na prawach powiatu) i województw, a także do poziomu powiatów ziemskich (tj. w ramach powiatów ziemskich).

Oceniając obecnie stosowane wpłaty powiatów do budżetu państwa (por. art. 30 ustawy o dochodach samorządu), należy wskazać, że nadwyżki podatkowe powiatów ziemskich i miast na prawach powiatów (w części dotyczącej dochodów powiatowych tych miast) są przejmowane w bardzo znaczącym stopniu (już wtedy gdy wskaźnik P jest powyżej 110\% średniej powiatowej Pp). Tak znaczące przejmowanie tych nadwyżek nie może być kontynuowane, ogranicza bowiem zbyt mocno samodzielność finansową powiatów i możliwości ich działania. Sądzę, że system wpłat w ramach powiatów ziemskich powinien być analogiczny do systemu gminnego. W systemie wpłat do budżetu państwa w samorządach gminnych przejmowanie nadwyżki dochodów podatkowych (tj. wpłat) stosowane jest dopiero wtedy, gdy średnia dochodów podatkowych na jednego mieszkańca gminy (G) jest wyższa niż 150\% średniej krajowej (Gg) ${ }^{3}$.

Z danych Ministerstwa Finansów (zamieszczonych na jego stronie internetowej) wynika, że w 2014 r. wpłaty do budżetu państwa dokonywane w systemie samorządu powiatowego (380 jednostek) dotyczą 57 przypadków (jest 57 wpłat). Z tego 38 wpłat dokonują miasta na prawach powiatu ${ }^{4}$, a 19 powiaty ziemskie. Z danych tych wynika, że miasta na prawach powiatu są znacznie silniejsze finansowo od powiatów ziem-

3 Por. A. Borodo (red.), Słownik finansów samorzqdu terytorialnego, Toruń 2015, s. 225 i n.

$4 \quad$ Przykładowo są to wpłaty takich miast jak: Wrocław (ponad $55 \mathrm{mln}$ ), Łódź (ponad 27 mln), Kraków (ponad $58 \mathrm{mln}$ ), Warszawa (ponad $500 \mathrm{mln}$ ), Gdańsk (ok. 29 mln), Gdynia (ok. 16 mln), Katowice (ponad 30 mln), Poznań (ponad 62 mln zł). W ustawie budżetowej na rok 2015 (Dz.U. z 2015 r., poz. 153) kwota wpłat powiatów do budżetu państwa ustalona została na około 1,062 mld zł (por. art. 27 ustawy). Wydaje się, że połowę tej kwoty wnosi Warszawa. 
skich. Wpłaty miast na prawach powiatów są źródłem finansowania działalności powiatów ziemskich. To ostatnie zjawisko jest wyrazem dużej ingerencji finansowej w dochody miast na prawach powiatu, które - jak już to podniesiono - wnoszą dwie wpłaty: gminną i powiatową. Nadmierna regulacja przejawia się także w tym, że jest kilka przypadków (np. w 2014 roku), że dana jednostka samorządu powiatowego zarówno dokonuje wpłat do budżetu państwa, jak i otrzymuje subwencję wyrównawczą.

Z danych Ministerstwa Finansów wynika też, że dochody podatkowe na jednego mieszkańca $w$ systemie gmin, w tym miast na prawach powiatu (wskaźnik Gg) dla celów obliczenia subwencji i wpłat w 2015 r. wynoszą 1435,18 zł. Dochody podatkowe na jednego mieszkańca w systemie powiatów (wskaźnik Pp) wynoszą 185,45 zł. Wskazuje to na olbrzymią różnicę $\mathrm{w}$ poziomie dochodów podatkowych gmin ( $\mathrm{w}$ tym miast na prawach powiatu) i powiatów ziemskich.

\section{Działalność gospodarcza powiatu i dochody z tej działalności}

Współcześnie powiaty ziemskie w Polsce są strukturą o niewielkich możliwościach finansowych, działającą w sferze usług socjalnych, oświatowych i administracyjnych. Jednostkami organizacyjnymi powiatów są głównie domy pomocy społecznej, szkoły ponadpodstawowe i placówki oświatowe, centrum pomocy rodzinie, zakłady opieki zdrowotnej, instytucje kultury, zarząd dróg powiatowych. Brak tu jednostek o charakterze gospodarczym (spółek powiatowych, samorządowych zakładów budżetowych), wykonujących zadania własne powiatu w sferze gospodarki komunalnej.

Ustawa z dnia 20 grudnia 1996 r. o gospodarce komunalnej ${ }^{5} \mathrm{w}$ art. 1 stanowi, że zasady i formy gospodarki komunalnej jednostek samorządu terytorialnego (a więc także powiatów ziemskich) polegają na wykonywaniu przez te jednostki zadań własnych (a więc także zadań własnych powiatu ziemskiego), w celu zaspokojenia zbiorowych potrzeb wspólnoty samorządowej. Gospodarka komunalna obejmuje w szczególności zadania

$5 \quad$ Tekst jedn. Dz.U. z 2011 r. Nr 45, poz. 236. 
o charakterze użyteczności publicznej, której celem jest zaspokajanie zbiorowych potrzeb ludności w drodze świadczenia usług powszechnie dostępnych. Gospodarka komunalna związana jest z wykonywaniem przez samorząd zadań własnych, które wymagają prowadzenia działalności usługowej lub produkcyjnej, osiąganiem wyniku finansowego, ustalaniem opłat lub cen.

Odnośnie do zagadnienia działalności gospodarczej powiatu art. 6 ust. 2 ustawy z 5 czerwca 1998 r. o samorządzie powiatowym ${ }^{6}$ stanowi, że powiat nie może prowadzić działalności gospodarczej wykraczającej poza zadania o charakterze użyteczności publicznej.

Jednak w świetle art. 4 ustawy o samorządzie powiatowym powinien on realizować zadania własne o charakterze ponadgminnym w zakresie transportu zbiorowego i dróg publicznych, kultury fizycznej i turystyki, gospodarki nieruchomościami, gospodarki wodnej, ochrony środowiska i przyrody, rolnictwa, leśnictwa i rybactwa, przeciwdziałania bezrobociu oraz aktywizacji lokalnego rynku pracy, działalności w zakresie telekomunikacji. Są to dziedziny w których działalność powiatu - mająca charakter działalności użyteczności publicznej - powinna być prowadzona. W tych dziedzinach powiaty ziemskie mogą tworzyć samorządowe zakłady budżetowe lub spółki prawa handlowego (art. 2 ustawy o gospodarce komunalnej). Ustawa z dnia 16 grudnia 2010 r. o publicznym transporcie zbiorowym $^{7}$ postanawia, że powiaty są organizatorami publicznego transportu zbiorowego.

Powiaty powinny rozwinąć swoją bazę gospodarczą - zakłady budżetowe, spółki, inne podmioty o charakterze gospodarczo-usługowym. Powinny być również strukturą gospodarczą, nie tylko administracyjną i socjalną. Jednostki gospodarcze powiatu ziemskiego powinny świadczyć usługi komunalne oraz - w miarę możliwości - dawać zatrudnienie mieszkańcom. Zakres działalności gospodarczej samorządu w innych syste-

Tekst jedn. Dz.U. z 2013 r., poz. 595 ze zm.

Dz.U. z 2011 r. Nr 5, poz. 13 ze zm. 
mach prawnych jest szeroki, rozwinięty ${ }^{8}$. W okresie II RP powiaty tworzyły m. in. tak istotne przedsięwzięcia jak komunalne kasy oszczędności ${ }^{9}$.

Własna działalność gospodarcza powiatów i działalność gospodarcza inspirowana przez organy powiatu powiększa bazę podatkową powiatu. Zwiększa dochody budżetów powiatów ziemskich pochodzące z udziałów w podatkach dochodowych i innych danin. Możliwe są dochody budżetowe powiatu bezpośrednio uzyskiwane z własnych zakładów i spółek.

\section{Podsumowanie}

Obecny system dochodów powiatów ziemskich i brak rozwiniętej działalności gospodarczej tego powiatu sprawiają, że powiaty stały się strukturą słabą, niezdolną do prowadzenia szerszej działalności. Znacznie większe niż obecnie środki podatkowe powinny być więc przekazane powiatom ziemskim. Biorąc pod uwagę obecne regulacje prawa o dochodach samorządowych, należy przyjąć, że współcześnie system dochodów powiatów ziemskich oparty powinien być głównie o dwa nowe, istotnie powiększone, udziały w podatkach dochodowych.

Wyrównania poziome (mające postać wpłat do budżetu państwa) zachodzące pomiędzy powiatami ziemskimi i miastami na prawach powiatu powinny być zniesione. Są to jednostki całkiem odmiennej natury, należą do innej klasy podmiotów. Powiatowa subwencja wyrównawcza i wpłata powiatu do budżetu państwa mogą być stosowane tylko na poziomie powiatów ziemskich. Natomiast miasta na prawach powiatu objęte byłyby systemem subwencji wyrównawczej i wpłat do budżetu państwa wyłącznie jako samorządy gminne.

8 Por. U. Cronauge, G. Westermann, Kommunale Unternehmen, Eigenbetriebe - Kapitalgesellschaften - Zweckverbände, Berlin 2003, s. 153 i n., I. Weinfeld, Skarbowość polska, Warszawa 1935, s. 418-419.

9 Por. Rozporządzenie Prezydenta Rzeczypospolitej z dnia 24 października 1934 r. o komunalnych kasach oszczędności (Dz.U. nr 95, poz. 860). Art. 3 ust. 1 tego rozporządzenia stanowił, że komunalne kasy oszczędności mogą być zakładane tylko przez miasta oraz związki samorządowe powiatowe i wojewódzkie, samodzielnie, bądź wspólnie przez utworzony w tym celu związek międzykomunalny. 


\section{Bibliografia:}

Borodo A. (red.), Słownik finansów samorzq̨u terytorialnego, TNOiK, Toruń 2015.

Cronauge U., Westermann G., Kommunale Unternehmen, Eigenbetriebe - Kapitalgesellschaften - Zweckverbände, Erich Schmidt Verlag, Berlin 2003.

Weinfeld I., Skarbowość polska, „Bibljoteka Prawnicza”, Warszawa 1935. 